\title{
GLL
}

Geomatics, Landmanagement and Landscape No. $4 \cdot 2019,109-122$

\section{VALIDATION OF NRTK MEASUREMENTS WITH MAC SOLUTION IN NADOWSKINET ACTIVE GEODETIC NETWORK}

\author{
Dawid Kudas, Agnieszka Wnęk
}

\begin{abstract}
Summary
The paper presents an analysis of the accuracy in determining the position of a point using Network Real Time Kinematic (NRTK) method, which applies the MAC solution based on the active network of NadowskiNet reference stations. The object of the study was a 24-hour time series of point coordinates registered with a 30-second recording interval. The collected data were compared with the catalog coordinates of the point. The average values of the mean square errors of $\mathrm{X}, \mathrm{Y}$ and $\mathrm{h}$ coordinates were determined, and their random nature was verified. An analysis was carried out in order to establish whether the distribution of errors obtained remains normal for parameters sufficiently close to the theoretical parameters.
\end{abstract}

\section{Keywords}

NRTK • MAC • NadowskiNet • active geodetic network

\section{Introduction}

Currently, the most popular measurement methods in geodesy are the methods of phased satellite measurements that allow determination of the position in real time. These methods include the Real Time Kinematic (RTK) and Network Real Time Kinematic (NRTK) methods, which determine the horizontal position with a centimetre-level error. The methods of RTK and NRTK measurements are very similar, whereas the difference lies in the way of generating corrections in real time. In the RTK method, corrections are sent from a single physical reference station to a mobile receiver. The limit for the use of the RTK method is the distance of the mobile receiver from the base station and the resulting measurement errors. Therefore, in the 1990s, a new RTK measurement method elaboration was proposed, the idea of which was based on the use of many reference stations. As the result, the infrastructure defined as the system of virtual reference stations (VRS) and the NRTK measurement method were created [Euler and Ziegler 2000, Townsend et al. 2000, Vollath et al. 2000, Rizos 2002, Rizos and Han 2003]. In the NRTK method that applies the VRS, the correction to the mobile receiver is sent from the virtual reference station, which is located near 
the mobile receiver. VRS is generated on the basis of the information concerning the approximate position of the mobile receiver, and the corrections are interpolated on the basis of adjustments obtained from the nearest physical reference stations. Real-time measurement methods are not free of errors. The results of RTK and NRTK measurements are affected, among other things, by clock errors, satellite orbit errors, the impact of the ionospheric and tropospheric delay, and the local effects [Grejner-Brzezinska et al. 2004, Wielgosz et al. 2005, Emardson et al. 2010, Kowalczyk 2011]. The NRTK method, thanks to the concept of using the network of base stations, enables better modelling and estimation of the values of these errors compared to the classical RTK method [Brown et al. 2005, Ouassou et al. 2018]. Currently, there are several methods available on the market for the position determination with the use of the NRTK method. These are the following methods: Master-Auxiliary Concept (MAC), Virtual Reference Station (VRS) [Vollath et al. 2000, Landau et al. 2002], Pseudo-Reference Station (PRS), Individualised Master-Auxiliary Corrections (i-MAX) and German Flächenkorrekturparameter (FKP) [Takac and Zelzer 2008].

\section{Master-Auxiliary Concept}

The MAC method assumes providing as much information about the network and errors as possible to the mobile receiver. This enables the selection of the optimal algorithms to determine the position of the mobile receiver [Brown et al. 2005]. The position determination with the use of the MAC method is as follows: data from the reference stations are sent to the network processing centre, then the uncertainty of the network is solved [Euler et al. 2001] and the choice of the optimal reference station is made. The latter will be used to estimate the corrections for the mobile receiver. In the next step, a network message is created, which is sent to the mobile receiver, and then locating errors for the position of the mobile receiver takes place. In the final stage, the position of the mobile receiver is determined with the use of the full information about the reference network [Brown et al. 2005, Ouassou et al. 2018]. The research, which compared the FKP and VRS methods with the MAC, demonstrated that the use of the MAC method is characterized by reliability in determining uncertainty, and accuracy. The MAC method offers the highest performance relative to the repair time [Brown et al. 2005]. The network of base stations plays a key role in the RTK, and especially in the NRTK measurements. The majority of countries have their own reference station networks. In Poland, besides the state-run ASG-EUPOS geodetic network, there are also commercial networks such as: VRSNet, Leica SmartNet, TPI Netpro, NadowskiNet. The results of NRTK measurements, which apply selected active base station networks, have been the subject of many studies [Uznański 2009, Kudas et al. 2016, Uznański 2016, Kudas et al. 2017, Uznański 2017].

\section{NadowskiNet Reference Stations Network}

The NadowskiNet network consists of 40 reference stations (as of 31 January 2019), equipped mainly with the Leica GR10 PRO receivers and the Leica AR10 GNSS 
antennas. The stations are located in the southern Poland in the Opolskie, Sląskie, Małopolskie, Podkarpackie and Świętokrzyskie regions (see Fig. 3). The antennas receive signals from the GPS, GLONASS, GALILEO and BeiDou systems. For the users registered at IP 213.241.57.10 address, different types of real time solutions with various reference data stream are available (Table 1).

Table 1. The types of real time solutions available in the NadowskiNet network

\begin{tabular}{|c|l|l|}
\hline Port & \multicolumn{1}{|c|}{ Correction type } & \multicolumn{1}{c|}{ Data stream } \\
\hline 2101 & NRTK (GPS\&GLO) & $\begin{array}{l}\text { NAVGEO_VRS_3_1, NAVGEO_MAX_3_1 } \\
\text { NAVGEO_FKP_3_1, NAVGEO_iMAX_3_1 }\end{array}$ \\
\hline 2101 & NRTK (GPS\&GLO\&GAL\&BDS) & $\begin{array}{l}\text { VRS_MSM4, } \\
\text { VRS_MSM5 }\end{array}$ \\
\hline 8080 & NRTK & $\begin{array}{l}\text { NAVGEO_VRS_3_1, NAVGEO_MAX_3_1 } \\
\text { NAVGEO_FKP_3_1, NAVGEO_iMAX_3_1 }\end{array}$ \\
\hline 2101 & RTK (automatic selection) & $\begin{array}{l}\text { NAVGEO_NAJBL_POJ_3_1 } \\
\text { NAJBL_POJ_MSM4, NAJBL_POJ_MSM5 }\end{array}$ \\
\hline 8082 & RTK (user choice is possible) & $\begin{array}{l}\text { XXXX_RTCM_3_1, } \\
\text { XXXX_MSM5 } \\
\text { XXXX - station ID }\end{array}$ \\
\hline
\end{tabular}

Source: www.nadowski.pl

Considering the dependence of indicating the connection of each NadowskiNet network station with the 4 nearest stations, the average length of the vectors determined in such a way, expressed in Cartesian coordinates PL ETRF2000 (epoch 2011.0), equals $44901 \mathrm{~m}$. The minimum length of the vector equals $24441 \mathrm{~m}$, while the maximum equals $77703 \mathrm{~m}$. The relative position of the network points in threedimensional space is represented by the division of vector lengths into classes, as described above (Fig. 1).

The classification of the area of the southern Poland depending on the distance from the nearest reference station of the NadowskiNet network is shown in Figure 2. The sum of the areas where the distance from the station in the plane belongs to the range from 0 to $10 \mathrm{~km}$ constitutes $18.0 \%$ of the total surface area of the indicated regions. In the case of distances between 0 and $20 \mathrm{~km}$, this is $63.9 \%$; and for the range from 0 to $30 \mathrm{~km}$, it is equal to $90.7 \%$. For the distances between 10 and $20 \mathrm{~km}$ from the station, this area occupies $45.9 \%$ of the total analysed area, and for the range from 20 to $30 \mathrm{~km}$, it equals $26.7 \%$. In most cases, the distance from the reference station remains in the range from 10 to $20 \mathrm{~km}$ (Table 2).

The aim of the research was to analyse the accuracy of the position determination with the application of the NRTK method, using the MAC method based on the 
commercial network of NadowskiNet reference stations. The test measurement was carried out on one measurement point, on which data were recorded over 24 hours with a 30 -second recording interval.

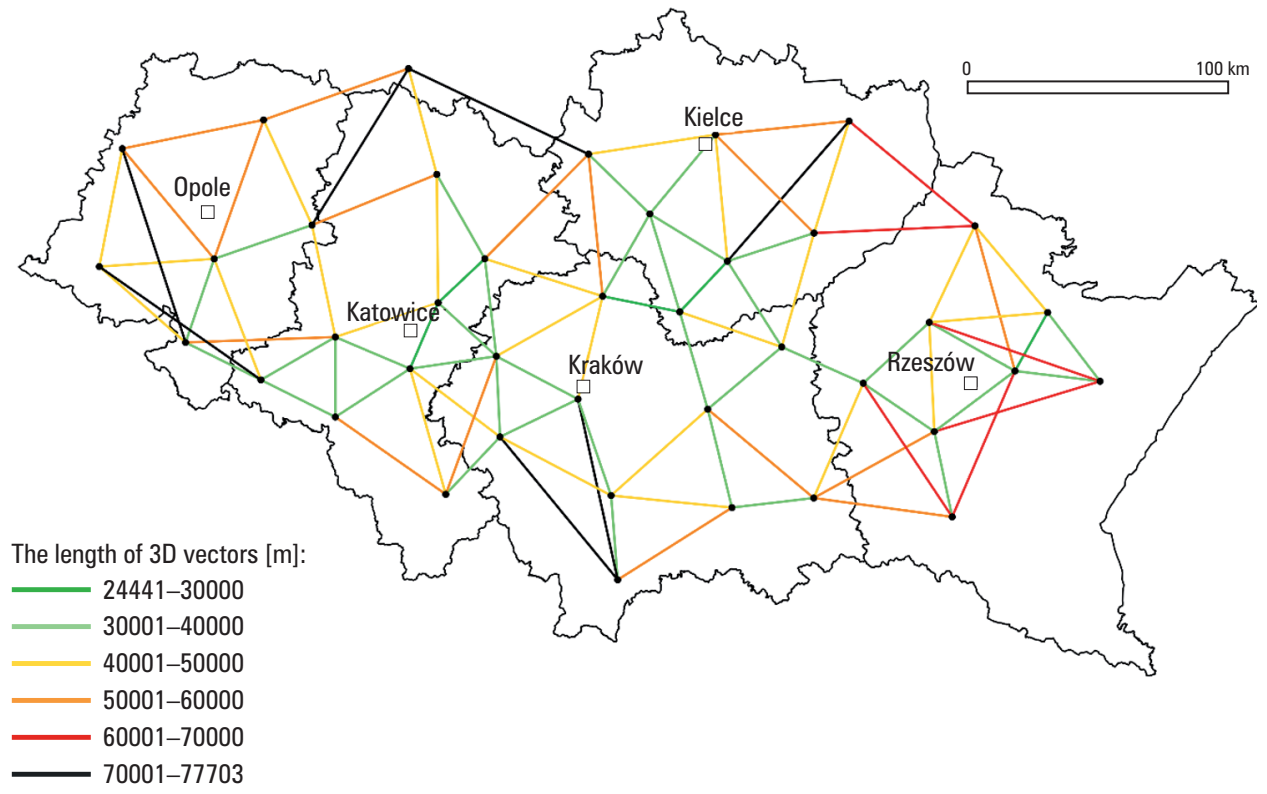

Source: Authors' own study

Fig. 1. Position of the NadowskiNet network points in three-dimensional space, represented by the lengths of the vectors

Table 2. The share of the area of distance zones in the area of regions

\begin{tabular}{|c|c|c|c|c|c|}
\hline \multirow{2}{*}{ Region (voivodeship) } & \multicolumn{5}{|c|}{ Share of buffer area in the area of regions [\%] } \\
\hline & $0-10[\mathrm{~km}]$ & $0-20[\mathrm{~km}]$ & $0-30[\mathrm{~km}]$ & $10-20[\mathrm{~km}]$ & $20-30[\mathrm{~km}]$ \\
\hline opolskie & 17.9 & 65.2 & 97.3 & 47.4 & 32.0 \\
\hline świętokrzyskie & 18.3 & 63.8 & 91.5 & 45.5 & 27.6 \\
\hline małopolskie & 20.3 & 73.7 & 97.6 & 53.4 & 23.9 \\
\hline podkarpackie & 13.9 & 51.1 & 75.4 & 37.2 & 24.3 \\
\hline śląskie & 20.9 & 69.7 & 98.5 & 48.8 & 28.8 \\
\hline
\end{tabular}

Source: Authors' own study 


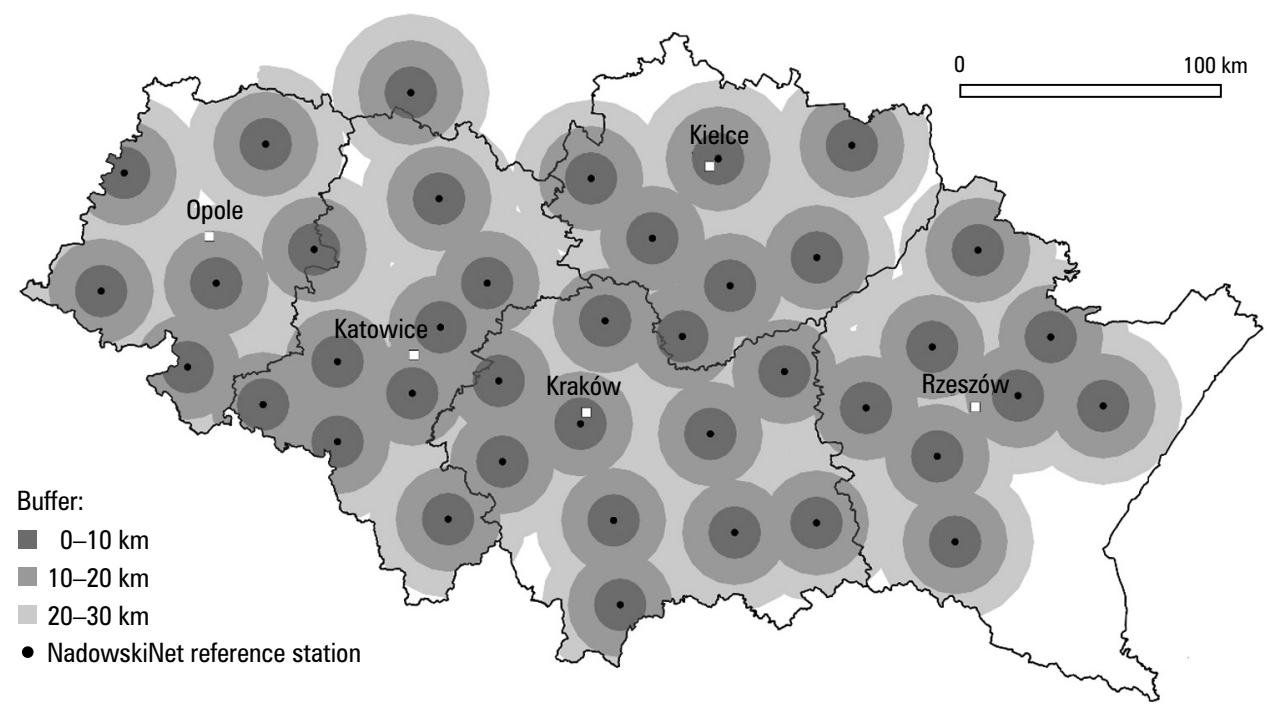

Source: Authors' own study

Fig. 2. The distance zones for individual reference stations in NadowskiNet

\section{Material and methods}

The measurement was carried out on 140th day of the year 2017 (140 DOY 2017) using the Trimble R8 GNSS/SPS88x Internal receiver integrated with the antenna, on a specially prepared measuring point with forced centering. The NAVGEO_MAX_3_1 correction was used in the RTMC 3 format (IP 213.241.57.10: 2101) (see Table 1). Due to the very good observation conditions (e.g. no horizon shading, no sources interfering with satellite signals), the value of the elevation mask equal to $5^{\circ}$ and the PDOP 6 mask were assumed on the point. The location of the measurement site in relation to the station is shown in Figure 3.

The nearest reference station was KRAK station located in Krakow (No. 173.1121810). The length of the 3D vector thereto equalled $14389 \mathrm{~m}$. Before the start of the measurement, the initialization of the receiver was verified at 2 points of the state network. Then, without switching off the receiver, a NRTK $24 \mathrm{~h}$ measuring session was carried out on the measuring point with a registration interval of $30 \mathrm{~s}$. During the measurement, the PDOP value was in the range between 1.0 and 1.6. The precise coordinates of the measuring point were obtained as a result of adjusting static satellite observations from two measurement sessions with lengths of 12 hours in relation to the nearby reference stations of the ASG-EUPOS network.

The data constituting a series of X, Y coordinates in the PL-2000/21 system and the h-coordinate in the Kronstadt 86 system were then used in order to determine the coordinates residuals, which were obtained as differences between the registered coordinates, and the coordinates determined from static measurement. 


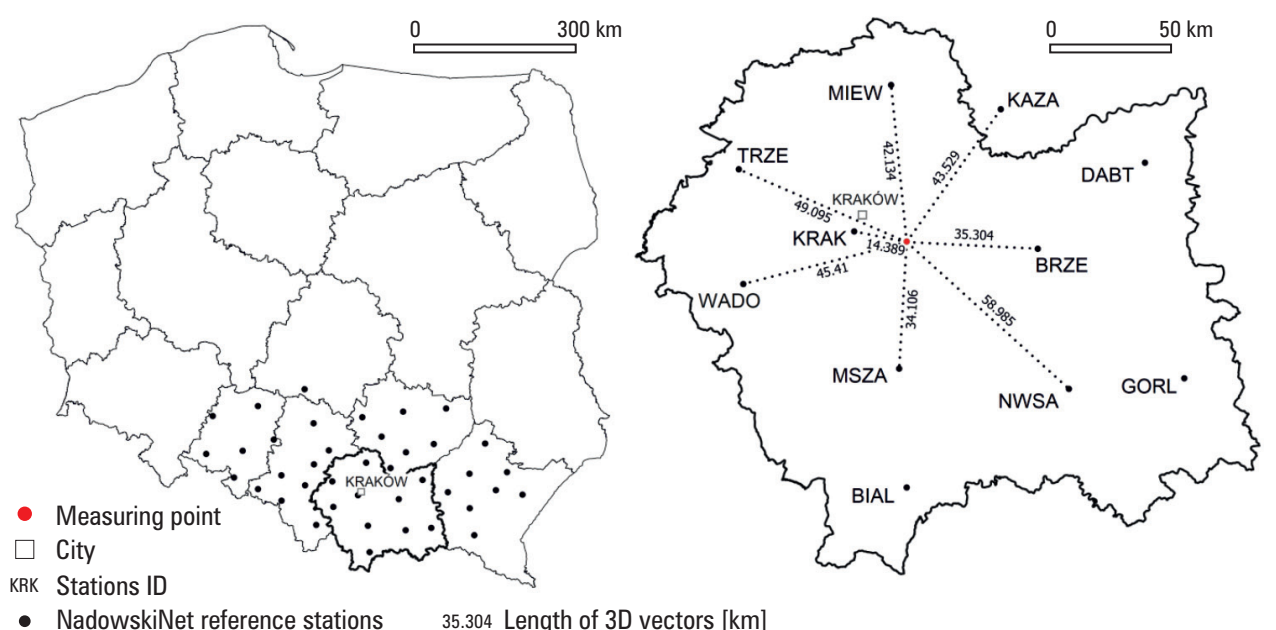

- NadowskiNet reference stations 35.304 Length of 3D vectors [km]

Source: Authors' own study

Fig. 3. The position of the measuring point against the background of the NadowskiNet network
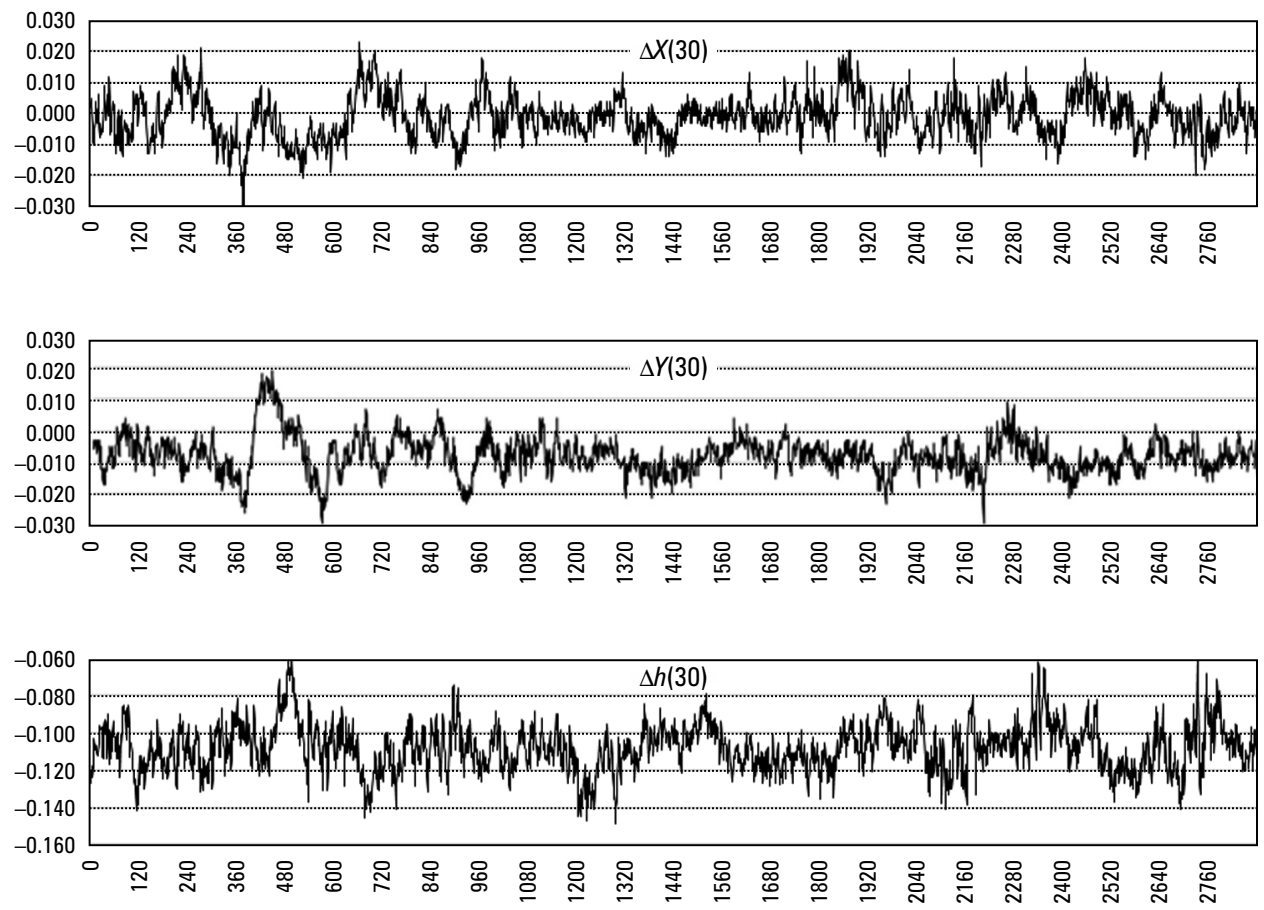

Source: Authors' own study

Fig. 4. The time series of residuals $\Delta \mathrm{X}(30), \Delta \mathrm{Y}(30), \Delta \mathrm{h}(30)$ during $24 \mathrm{~h}$ 
On the basis of the test set containing residuals $\Delta X(30), \Delta Y(30)$ and $\Delta h$ (30) (Fig. 4 ), four new sets were created (Fig. 5). These sets were created by selecting residuals at intervals of $60 s-S 1,300 s-S 2,600 s-S 3$ and $900 s-S 4$. The sets connecting respectively 1440, 288, 144 and 96 data items were obtained. For each of the sets, the mean square error of a single observation was estimated.

\begin{tabular}{|c|c|c|}
\hline & & $\begin{array}{l}\text { Set } n\left(S_{n}\right) \\
\Delta X_{j}\left(i_{s}\right), \Delta Y_{j}\left(i_{s}\right), \Delta h_{j}\left(i_{s}\right)\end{array}$ \\
\hline \multirow{2}{*}{$\begin{array}{l}\quad \begin{array}{l}\text { Time series of } \\
\quad \text { coordinates } \\
\boldsymbol{X}_{\boldsymbol{j}}(\boldsymbol{i}), \boldsymbol{Y}_{\boldsymbol{j}}(\boldsymbol{i}), \boldsymbol{h}_{\boldsymbol{j}}(\boldsymbol{i}) \\
\text { where: } \\
i=30 \\
j \in\{1,2,3, \ldots, 2880\}\end{array}\end{array}$} & $\begin{array}{c}\text { Time series of } \\
\text { residuals } \\
\Delta \boldsymbol{X}_{j}(\boldsymbol{i}), \Delta \boldsymbol{Y}_{j}(\boldsymbol{i}), \boldsymbol{\Delta} \boldsymbol{h}_{j}(\boldsymbol{i})\end{array}$ & $\begin{aligned} \text { where: } & n=1 \\
& i_{s}=2 i \\
& j \in\left\{1,2,3, \ldots,\left|S_{n}\right|\right\}\end{aligned}$ \\
\hline & $\begin{array}{l}\text { where: } \\
i=30 \\
j \in\{1,2,3, \ldots, 2880\}\end{array}$ & \multirow{2}{*}{$\begin{array}{l}\text { Set } n\left(\boldsymbol{S}_{n}\right) \\
\begin{aligned} \Delta \boldsymbol{X}_{j}\left(i_{s}\right), & \Delta \boldsymbol{V}_{j}\left(i_{s}\right), \Delta \boldsymbol{h}_{j}\left(\boldsymbol{i}_{s}\right) \\
\text { where: } & n \in\{2,3,4\} \\
& i_{s}=10 i(n-1) \\
& j \in\left\{1,2,3, \ldots,\left|S_{n}\right|\right\}\end{aligned}\end{array}$} \\
\hline $\begin{array}{l}\text { Irerval } \\
\text { set interval }\end{array}$ & - set cardinality & \\
\hline
\end{tabular}

Source: Authors' own study

Fig. 5. Flow chart of the distribution of measurement data

In order to check whether the residuals obtained are of random nature, an analysis was carried out to verify whether the residuals distribution is normal, with parameters sufficiently close to the theoretical parameters. For the analysed test sets, basic statistics were estimated, including the measurements of the shape of the distribution (kurtosis and skewness). We verified whether there exists a dependency between successive data defining the autocorrelation function (ACF) and the partial autocorrelation function (PACF) for a set of residuals with a 30 second interval of registration. The ACF function is a measure of the linear correlation between observations removed from each other by a distance of specific number of time units, and the PACF function makes it possible to determine the direct relationship between observations distant from each other by a specific number of time units. For the purpose of the final verification of the distribution normality of the residuals of the point coordinates, tests for normality of the distribution were conducted. The test with the highest power was used, i.e. the Shapiro-Wilk test, but also weaker tests, such as Kolmogorov-Smirnov and AndersonDarling. In these tests a null hypothesis is made, which assumes that the distribution of the analysed features is normal, while the alternative hypothesis assumes that the distribution of the analysed feature is not normal. Testing the normality of the distribution was performed assuming a significance level of 0.05 .

The statistical analysis was carried out in the $\mathrm{R}$ environment [R Core Team 2018] and using packages such as: moments [Komsta and Novomestky 2015], olsrr [Hebbali 2018], and forecast [Hyndman and Khandakar 2008, Hyndman et al. 2019]. 


\section{Results}

Considering the main test set of residuals $\Delta X(30), \Delta Y(30)$ and $\Delta h$ (30), a mean square error of one measurement equal to $0.007 \mathrm{~m}$ for $\Delta X$ (30), $0.010 \mathrm{~m}$ for $\Delta Y(30)$ and 0.109 $\mathrm{m}$ for $\Delta h$ was obtained. Based on the location of the position $\Delta X$ (30) and $\Delta Y$ (30) on a plane (Fig. 6), it can be observed that in most cases they take negative values, especially in the case of $\Delta Y$ (30). The rounding of residuals to the nearest centimetre using the Krylov-Bradis rule leads us to conclude that among 25 different residuals on the plane, in 14 cases $\Delta Y(30)$ takes values below zero, and so does $\Delta X(30)$, in 11 cases.
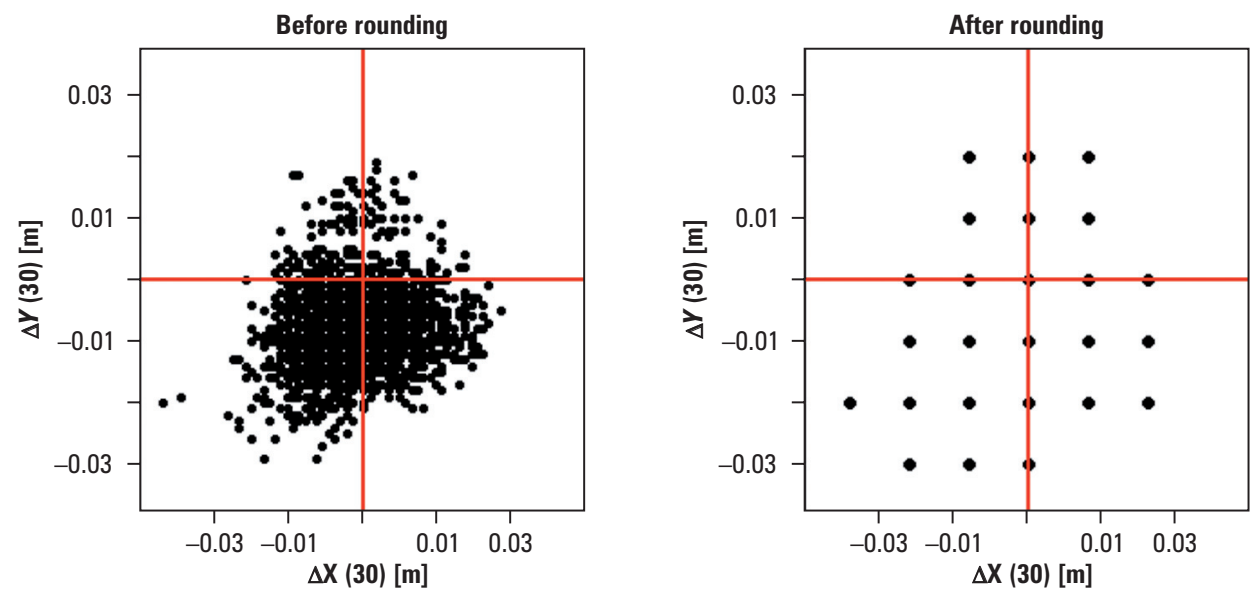

Source: Authors' own study

Fig. 6. The location of residuals $\Delta X(30)$ and $\Delta Y(30)$ on the plane
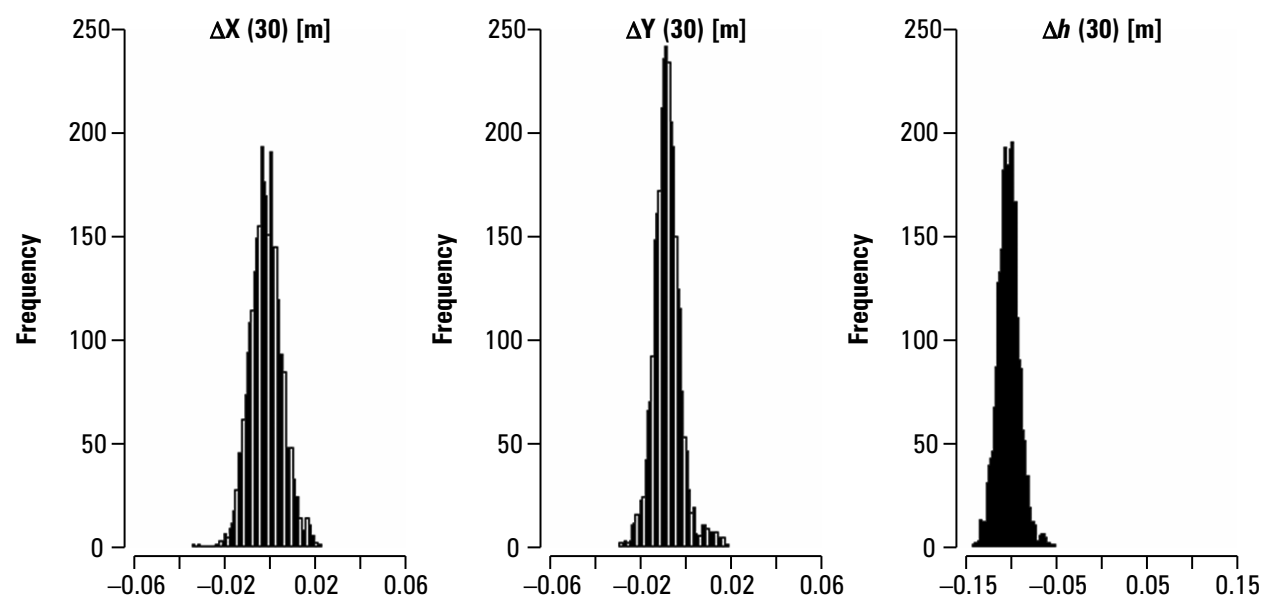

Source: Authors' own study

Fig. 7. Histograms of residuals $\Delta X(30), \Delta Y(30)$, and $\Delta h(30)$ 
The histograms depicted in Figure 7 are characterized by a slenderness of the distribution curve, leading to an observation that in all cases residual values are concentrated around the mean values. The average residuals, however, take the following values: $-0.001 \mathrm{~m}$ for $\Delta X(30), 0.008 \mathrm{~m}$ for $\Delta Y(30)$, and $-0.108 \mathrm{~m}$ for $\Delta h(30)$. The concentration of residuals around the mean value is also confirmed by the obtained kurtosis values (Table 3 ), which for all three residuals are significantly greater than 0 . The analysis of histograms shows that in the case of $\Delta Y(30)$ and $\Delta h(30)$ the frequency graph is skewed, which is also confirmed by the obtained skewness values of 0.55 and 0.23 , respectively.

Table 3. Basic statistics of residuals $\Delta X(30), \Delta Y(30)$, and $\Delta h(30)$

\begin{tabular}{|l|c|c|c|}
\hline & $\Delta X(30)$ & $\Delta Y(30)$ & $\Delta h(30)$ \\
\hline Mean $[\mathrm{m}]$ & -0.001 & -0.008 & -0.108 \\
\hline Standard deviation $[\mathrm{m}]$ & 0.007 & 0.006 & 0.013 \\
\hline Variance $[\mathrm{m}]$ & 0.000 & 0.000 & 0.000 \\
\hline Minimum $[\mathrm{m}]$ & -0.034 & -0.029 & -0.149 \\
\hline Maximum $[\mathrm{m}]$ & 0.023 & 0.019 & -0.054 \\
\hline Kurtosis & 0.42 & 2.14 & 0.64 \\
\hline Skewness & 0.15 & 0.55 & 0.23 \\
\hline
\end{tabular}

Source: Authors' own study

In order to verify whether there is a dependency between successive data, the autocorrelation function (ACF) was determined. Figure 8 presents the values of the ACF functions obtained for $\Delta X(30), \Delta Y(30)$, and $\Delta h$ (30) respectively, and the dotted blue line determines the level of their statistical significance.

In all three cases, the ACF function is positive and its values disappear slowly, suggesting that the residuals may contain a deterministic component. Basing on the analysis of the PACF function graphs, it is clearly visible that this function achieves a 0.8 value in all three cases for the lag $=1$, which also suggests the existence of a deterministic component. The analysis of the autocorrelation, therefore, does not allow us to conclude that the obtained residuals are independent.

In order to verify whether the distribution of the analysed residuals is normal, tests for normality of the distribution have been carried out. The Shapiro-Wilk test was used, as well as the Kolmogorov-Smirnov and Anderson-Darling tests. Obtained p-values equal to 0.00 for $\Delta X(30), \Delta Y(30)$, and $\Delta h$ (30) in all three tests indicate the necessity of rejecting the null hypothesis about the normality of the examined feature distribution in favour of the alternative hypothesis. The results obtained for the test suggest the existence of dependencies between residuals. In order to verify whether the observed 
correlation does not result from a short time interval between successive coordinate records, the analyses were carried out for the sets created by selecting residuals at intervals of $60 s-S 1,300 s-S 2,600 s-S 3$, and $900 s-S 4$. The mean square error of a single observation in all sets reached the same values as in the test set, i.e. $0.007 \mathrm{~m}$ for $\Delta X$, $0.010 \mathrm{~m}$ for $\Delta Y$, and $0.109 \mathrm{~m}$ for $\Delta h$. The basic statistics of residuals for sets S1, S2, S3, and S4 (Table 4) for the mean value, standard deviation and variance, do not differ significantly from the values obtained for the test set.
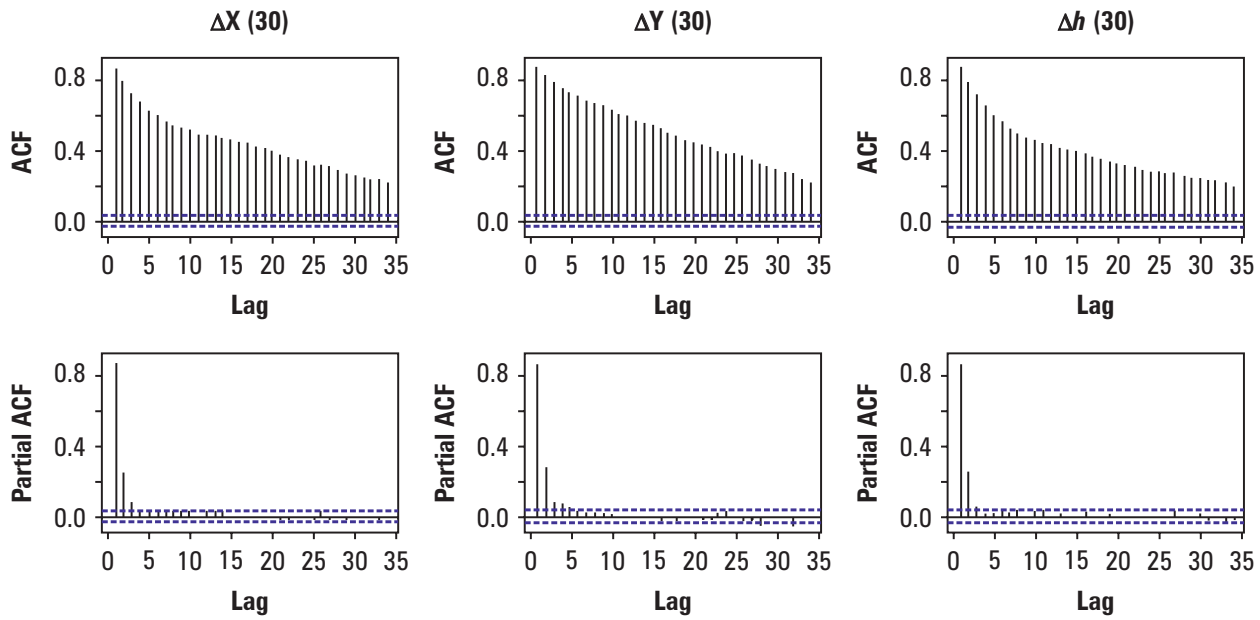

Source: Authors' own study

Fig. 8. Autocorrelation function (ACF) and partial autocorrelation function (PACF) of residuals $\Delta X(30), \Delta Y(30)$, and $\Delta h(30)$

On the other hand, changes were noted for the asymmetry of the distribution, while the correlation between changes in their value and the time of data recording is unremarkable. In the case of $\Delta X$ kurtosis values, the values nearest to 0 were recorded for the S2 and S3 sets, however, in the case of skewness, it is positive for all sets, reaching the lowest values for sets S1 and S3. For $\Delta Y$ in all sets the values of kurtosis and skewness are positive. The minimum kurtosis value was noted for the S2 set, and the lowest skewness value for the S4 set. In the case of $\Delta h$, the value closest to 0 for kurtosis and skewness occurs for set S3. The analysis of kurtosis and skewness in the surveyed sets does not allow stating clearly which of the sets is characterized by the normal distribution.

For the sets S1, S2, S3 and S4, tests for normality of the distribution were carried out. On the basis of p-value (Table 5), it can be concluded that there are no grounds for rejecting the null hypothesis assuming that the sample comes from a population with a normal distribution only in the following cases: for $\Delta X$ belonging to the sets $\mathrm{S} 2$ and $\mathrm{S} 3$, and for $\Delta h$ belonging to the sets S3 and S4. 
Table 4. Statistics of residuals $\Delta X(30), \Delta Y(30)$ and $\Delta h$ (30) for the sets S1, S2, S3 and S4

\begin{tabular}{|c|c|c|c|c|c|c|}
\hline Residuals & Set & $\begin{array}{c}\text { Mean } \\
{[\mathrm{m}]}\end{array}$ & $\begin{array}{c}\text { Standard deviation } \\
{[\mathrm{m}]}\end{array}$ & $\begin{array}{l}\text { Variance } \\
{[\mathrm{m}]}\end{array}$ & Kurtosis & Skewness \\
\hline \multirow{4}{*}{$\Delta X$} & $\mathrm{~S} 1$ & -0.001 & 0.007 & 0.000 & 0.31 & 0.14 \\
\hline & S2 & -0.001 & 0.007 & 0.000 & -0.04 & 0.19 \\
\hline & S3 & -0.002 & 0.007 & 0.000 & -0.07 & 0.14 \\
\hline & $\mathrm{S} 4$ & -0.001 & 0.006 & 0.000 & -0.45 & 0.52 \\
\hline \multirow{4}{*}{$\Delta Y$} & $\mathrm{~S} 1$ & -0.008 & 0.006 & 0.000 & 2.17 & 0.52 \\
\hline & $\mathrm{S} 2$ & -0.008 & 0.006 & 0.000 & 1.60 & 0.45 \\
\hline & S3 & -0.008 & 0.005 & 0.000 & 1.92 & 0.64 \\
\hline & S4 & -0.008 & 0.005 & 0.000 & 2.32 & 0.30 \\
\hline \multirow{4}{*}{$\Delta h$} & $\mathrm{~S} 1$ & -0.108 & 0.013 & 0.000 & 0.57 & 0.22 \\
\hline & S2 & -0.108 & 0.013 & 0.000 & 0.56 & 0.32 \\
\hline & S3 & -0.108 & 0.012 & 0.000 & 0.09 & 0.20 \\
\hline & S4 & -0.108 & 0.012 & 0.000 & -0.26 & -0.20 \\
\hline
\end{tabular}

Source: Authors' own study

Table 5. P-value of normality tests for residuals $\Delta X(30), \Delta Y(30)$, and $\Delta h$ (30) for the sets $\mathrm{S} 1, \mathrm{~S} 2$, S3 and S4

\begin{tabular}{|l|c|c|c|c|c|c|c|c|c|c|c|c|}
\hline & \multicolumn{4}{|c|}{$\Delta X$} & \multicolumn{4}{c|}{$\Delta Y$} & \multicolumn{5}{c|}{$\Delta h$} \\
\hline Set & S1 & S2 & S3 & S4 & S1 & S2 & S3 & S4 & S1 & S2 & S3 & S4 \\
\hline Shapiro-Wilk & 0.00 & 0.29 & 0.76 & 0.01 & 0.00 & 0.00 & 0.00 & 0.00 & 0.00 & 0.02 & 0.79 & 0.76 \\
\hline Kolmogorov-Smirnov & 0.00 & 0.24 & 0.61 & 0.25 & 0.00 & 0.13 & 0.13 & 0.39 & 0.03 & 0.61 & 0.91 & 0.77 \\
\hline Anderson-Darling & 0.00 & 0.09 & 0.39 & 0.02 & 0.00 & 0.00 & 0.00 & 0.02 & 0.00 & 0.20 & 0.79 & 0.58 \\
\hline
\end{tabular}

Source: Authors' own study

\section{Conclusions}

The paper presents the analysis of the accuracy of position determination using the NRTK method, applying the MAC method and corrections received from the commercial NadowskiNet network of reference stations. Specifically, the pertinent research was based on the verification whether the coordinate's residuals are of random character. It was estimated that the mean residual values are equal to $-0.001 \mathrm{~m}$ for $\Delta X, 0.008 \mathrm{~m}$ for $\Delta Y$, and $-0.108 \mathrm{~m}$ for $\Delta h$. The range of the obtained residuals for $\Delta X$ equals $0.057 \mathrm{~m}$, 
for $\Delta Y$ it equals $0.048 \mathrm{~m}$, and $0.095 \mathrm{~m}$ for $\Delta h$. The mean values for $\Delta X$ and $\Delta h$ differ from the mean values obtained by Uznański [2017], who obtained the mean value for $\Delta X$ equal to $0.004 \mathrm{~m}$ and for $\Delta h$, equal to $-0.05 \mathrm{~m}$. The discrepancies in the mean value may be the result of the different methods used to determine corrections to satellite observations. In this paper, only the MAC method was used, which is considered one of the most accurate, whereas Uznański [2017] used all available methods of correction streams. Basing on the obtained mean values, it can be stated that the $X$ and $Y$ coordinates determined using the NRTK method and the MAC stream, based on the network of NadowskiNet reference stations, are characterized by the error below $0.01 \mathrm{~m}$. The worse result is obtained, however, in the case of coordinate $h$, where the mean error exceeds the permissible value, which was defined for determining the height of points in legal regulations [Ordinance 2011]. The studies carried out regarding the normality of the distribution of the analysed residuals showed that these residuals did not take the random values. The observed correlation between the residuals from a 30 -second set can result from a very short time interval between successive measurements. This is related to the occurrence of the invariable satellite conditions during the measurement, which in turn means a similar determination of error values for the position of the mobile receiver. Extending the interval between successive measurements did not show the randomness of the errors obtained. The results may have been affected by the small distance between the measurement site and the nearest reference station.

This research project was financed by the Ministry of Science and Higher Education of the Republic of Poland for the statutory activities SUB/2019-0318000000-D310 and from the grant No. W301/KG/2017.

\section{References}

Brown N., Keenan R., Richter B., Troyer L. 2005. Advances in ambiguity resolution for RTK applications using the new RTCM V3.0 Master-Auxiliary messages. Proceedings of ION GNSS 2005, Long Beach, California, September 13-16.

Brown N., Geisler I., Troyer L. 2006. RTK Rover Performance using the Master-Auxiliary Concept. Journal of Global Positioning Systems, 5.10.5081/jgps.5.1.135.

Emardson R., Jarlemark P., Johansson J., Bergstrand S., Lidberg M., Jonsson B. 2010. Measurement Accuracy in Network-RTK. Bollettino Geod. Sci. Affini.

Euler H.-J., Ziegler C. 2000. Advances in ambiguity resolution for surveying type applications. 13th Int. Tech. Meeting of the Satellite Div. of the U.S. Institute of Navigation, Salt Lake City, Utah, 19-22 September 2000, 95-103.

Euler H-J., Keenan C.R., Zebhauser B.E., Wuebbena G. 2001. Study of a Simplified Approach in Utilizing Information from Permanent Reference Station Arrays. Proceedings of ION GPS 2001, Salt Lake City, Utah, September 11-14.

Grejner-Brzezinska D., Wielgosz P., Kashani I., Smith D., Spencer P., Robertson D., Mader G. 2004. An analysis of the effects of different network-based ionosphere estimation models on rover positioning accuracy. Positioning, 1,8 .

Hebbali A. 2018. Olsrr: Tools for Building OLS Regression Models, R package version 0.5.2, https://CRAN.R-project.org/package $=$ olsrr 
Hyndman R., Athanasopoulos G., Bergmeir C., Caceres G., Chhay L., O’Hara-Wild M., Petropoulos F., Razbash S., Wang E., Yasmeen F. 2019. Forecast: Forecasting functions for time series and linear models, R package version 8.5, http://pkg.robjhyndman.com/forecast

Hyndman RJ., Khandakar Y. 2008. Automatic time series forecasting: The forecast package for R. Journal of Statistical Software, 26 (3), 1-22, http://www.jstatsoft.org/article/view/v027i03>.

Komsta Ł., Novomestky F. 2015. Moments: Moments, cumulants, skewness, kurtosis and related tests, R package version 0.14, https:/CRAN.R-project.org/package=moments

Kowalczyk K. 2011. Analiza błędów generowanych podczas pomiaru szczegółów sytuacyjnych metodą GPS RTK. Acta Sci. Pol., ser. Geod. Descr., Terr. 10 (1), 5-22.

Kudas D., Szylar M., Cegielska K. 2016. Daily measurement of point coordinates using RTN GPS method. Episteme, 30 (II), 511-524.

Kudas D., Wnęk A., Czempas T. 2017. Compatibility of RTN solutions in selected active geodetic networks. Infrastructure and Ecology of Rural Areas, II, 767-781. 10.14597/infraeco.2017.2.2.059.

Landau H., Vollath U., Chen X. 2002. Virtual Reference Station Systems, Positioning, 1, 2.

Ordinance 2011. Rozporządzenie MSWiA z 09.11.2011 r. w sprawie standardów technicznych wykonywania geodezyjnych pomiarów sytuacyjnych i wysokościowych oraz opracowywania i przekazywania wyników tych pomiarów do państwowego zasobu geodezyjnego i kartograficznego.

Ouassou M., Natvig B., Jensen A.B.O., Gåsemyr J.I. 2018. Reliability Analysis of Network Real-Time Kinematic. Journal of Electrical and Computer Engineering, 8260479, https://doi. org/10.1155/2018/8260479

R Core Team 2018. R: A language and environment for statistical computing. R Foundation for Statistical Computing, Vienna, Austria, https://www.R-project.org

Rizos C. 2002. Network RTK research and implementation - a geodetic perspective. Journal of Global Positioning Systems, 1 (2), 144-150.

Rizos C., Han S. 2003. Reference station network based RTK systems - concepts and progress. Wuhan University Journal of Natural Sciences, 8, 566-574, 10.1007/BF02899820.

Takac F., Zelzer O. 2008. The Relationship Between Network RTK Solutions MAC, VRS, PRS, FKP and i-MAX. Proceedings of the 21st International Technical Meeting of the Satellite Division of The Institute of Navigation (ION GNSS 2008), Savannah, GA, USA, 16-19 September 2008.

Townsend B., Van Dierendonck A.J., Neumann J., Petrovski I., Kawaguchi S., Torimoto H. 2000. A proposal for standardized network RTK messages. 13th Int. Tech. Meeting of the Satellite Div. of the U.S. Institute of Navigation, Salt Lake City, Utah, 19-22 September 2000, 1871-1878.

Uznański A. 2009. Estymacja precyzji i dokładności wyników RTN w odniesieniu do sieci ASG-EUPOS. Zeszyty Naukowo-Techniczne Stowarzyszenia Inżynierów i Techników Komunikacji Rzeczpospolitej Polskiej. Oddział w Krakowie, 149, 595-610.

Uznański A. 2016. Pozycjonowanie RTN w odniesieniu do różnych sieci stacji referencyjnych w Polsce. Zeszyty Naukowo-Techniczne Stowarzyszenia Inżynierów i Techników Komunikacji Rzeczpospolitej Polskiej. Oddział w Krakowie, cz. 1.

Uznański A. 2017. Analiza porównawcza jakości pomiarów RTN nawiązanych do wszystkich sieci referencyjnych w Polsce. Zeszyty Naukowo-Techniczne Stowarzyszenia Inżynierów i Techników Komunikacji Rzeczpospolitej Polskiej, 1 (112).

Vollath U., Buecherl A., Landau H., Pagels C., Wagner B. 2000. Multi-base RTK positioning using Virtual Reference Stations. 13th Int. Tech. Meeting of the Satellite Div. of the U.S. Institute of Navigation, Salt Lake City, Utah, 19-22 September 2000, 123-131.

Wielgosz P., Kashani I., Grejner-Brzezinska D. 2005. Journal of Geodesy, 79, 9, 524-531, https://doi.org/10.1007/s00190-005-0003-y 
Mgr inż. Dawid Kudas

Uniwersytet Rolniczy w Krakowie

Katedra Geodezji

30-198 Kraków, ul. Balicka 253a

e-mail: dawid.kudas@gmail.com

ORCID: https://orcid.org/0000-0003-1109-114X

Dr inż. Agnieszka Wnęk

Uniwersytet Rolniczy w Krakowie

Katedra Geodezji

30-198 Kraków, ul. Balicka 253a

e-mail: ag.wnek@urk.edu.pl

ORCID: https://orcid.org/0000-0001-8669-2519 